\title{
REVISTA NOVA ESCOLA E EDUCAÇÃO FÍSICA (1986 - 1997): FASE DA ADESÃO À EDUCAÇ̃̃ PELO MOVIMENTO
}

Fábio Luís Santos Nunes ${ }^{2}$

\section{RESUMO}

Este artigo possui como objetivo analisar quais concepções do componente Educação Física historicamente foram veiculadas pela Revista Nova Escola entre 1986 e 1997. Este impresso é destinado aos profissionais do Ensino Básico, possui edições mensais e é publicado, desde março de 1986, pela Fundação Victor Civita, órgão ligado a Editora Abril. Possui temas relacionados ao Ensino Fundamental abrangendo assuntos ligados a todos os componentes desta etapa da Educação Básica. Estudado à luz da interpretação historiográfica thompsoniana, que elimina procedimentos autoconfirmadores, o periódico foi compreendido como um objeto real, concreto e cognoscível do ponto de vista histórico que enquanto produto material é provisório e passível de mudanças e releituras. Constatouse, a partir das reportagens sobre a área que trouxeram sugestões de conteúdos e relatos de práticas pedagógicas desenvolvidas por professores de Educação Física, na maioria de escolas públicas de todas as regiões do país, que entre 1986 e 1997, a Revista Nova Escola veiculou, predominantemente, a concepção psicologizante de Educação Física, no entanto, foi possível constatar que o impresso também veiculou, com menos ênfase, a concepção crítica ou progressista da área.

Palavras-chave: Revista Nova Escola, Educação Física, Concepções Pedagógicas.

\section{REVISTA "NOVA ESCOLA" Y EDUCACIÓN FÍSICA (1986 - 1997): FASE DE LA ADHESIÓN A LA EDUCACIÓN POR EL MOVIMIENTO}

\section{RESUMEN}

Este artículo posee como objetivo analizar cuales concepciones del componente Educación Física historicamente fueron publicadas por la Revista "Nova Escola" entre 1986 y 1997. Este magazine es hecho para profesionales de la Enseñanza Media con ediciones mensuales desde marzo de 1986, por la Fundación Victor Civita, órgano que tiene ligación con la Editora Abril. Trata temas relacionados a la Enseñanza Fundamental abarcando asuntos relacionados a todos los componentes de esta parte de la Enseñanza Basica. Fue basado en la interpretación historiográfica thompsoniana, que suprime procedimientos autoconfirmadores, la publicación fue hecha con un objetivo real, concreto y de fácil entendimiento del punto de vista histórico que mientras producto material es provisional y pasible de cambios y relecturas. Se constató, desde reportajes sobre la área que han trazido sugerencias de contenidos y relatos de prácticas pedagógicas desarrolladas por maestros de Educación Física, en la mayoría de las escuelas públicas de todas la regiones del país, que entre 1986 y 1997, la Revista "Nova Escola, publicó, predominantemente, la concepción psicologizante de Educación Física, no obstante, fue posible constatar que la revista también publicó, con menor énfasis, la concepción crítica o progresista de la área.

Palabras clave: Revista "Nova Escola”, Educación Física, Concepciones Pedagógicas.

\section{Introdução}

A Revista Nova Escola, periódico destinado aos profissionais do Ensino Básico, é uma publicação que sempre está disponível nas diversas escolas brasileiras. Esse impresso possui edições mensais, é ligado à Fundação Victor Civita e publicado pela Editora Abril, 
apresentando como sua missão principal contribuir para a melhoria da qualidade da Educação Básica possuindo reportagens a respeito de temáticas educacionais, conferindo grande espaço, principalmente, para matérias com sugestões de conteúdos para aulas e veiculando os relatos sobre experiências pedagógicas realizadas por professores de todo o país. Seus temas são, em grande parte, os que se relacionam com o Ensino Fundamental abrangendo assuntos ligados a todos os componentes presentes nesta etapa da Educação Básica.

Considerando as elevadas tiragens da Revista Nova Escola que, entre janeiro a agosto de 2012, chegaram a 682.614 exemplares $^{3}$ e levando em conta que o periódico, através de convênio com o Ministério da Educação (MEC) e diferentes secretarias estaduais de Educação, tem sua distribuição gratuita nas escolas públicas de todas as regiões do país, pode-se supor que se trata de um impresso educacional ao qual a maioria dos professores da rede pública tem acesso. Assim, esses dados fazem-me inferir que a Revista Nova Escola apresenta junto aos professores do Ensino Infantil e Ensino Fundamental grande repercussão e, nesse sentido, percebo como os impressos, notadamente os que se destinam aos docentes, se constituem em uma fértil fonte e objeto para pesquisas em Educação ${ }^{4}$.

No que se refere a Revista Nova Escola, é relevante salientar que seu surgimento ocorreu em 1986, momento de significativa importância para o país, já que estava havendo o processo de redemocratização ${ }^{5}$ em que na Educação, desde a década de 1970 por meio de vários educadores ${ }^{6}$, foram realizadas severas críticas a função da escola pública na sociedade brasileira. E nesse contexto, a Educação Física, desde o início dos anos 1980, foi atingida por denúncias de que precisava entrar em crise para superar a proposição que a ela dava suas bases, ou seja, a esportiva ${ }^{7}$ com predominância no paradigma das ciências biológicas, e, desse modo, parte de seus intelectuais enunciaram um discurso com engajamento político, que procurou tratar de modo predominante a função da Educação Física escolar a partir de uma teoria crítica da Educação e da sociedade. Nesse clima de questionamento se consolidam, conforme as observações de Bracht (1999), a existência de três concepções ${ }^{8}$ de Educação Física escolar na cena brasileira. A primeira, denominada pelo autor de biologizante, possui nos termos "atividade física" e "exercícios físicos" marcada a ideia de que o papel da área é contribuir para o desenvolvimento da aptidão física, se embasando nas ciências biológicas, em que

A definição clássica de EF [Educação Físca], nessa perspectiva, é a que a considera como disciplina que, por meio das atividades físicas, promove a educação integral do ser humano - mas, a conotação, na prática, é a do desenvolvimento físico-motor ou da aptidão física, servindo a "educação integral do ser humano" para satisfazer/caracterizar o discurso pedagógico (BRACHT, 1999, p.43).

Como segunda concepção de Educação Física, conforme Bracht (1999), há a de conotação psicologizante, em que ocorre uma mudança de denominação do objeto da área, ainda que o paradigma ou concepção nem sempre seja alterado, e se concede centralidade aos termos "movimento humano", "motricidade humana". Essa perspectiva dá ao movimento importância para o desenvolvimento integral da criança, sendo esse o papel da disciplina. Assim, a Educação Física é classicamente definida como educação pelo movimento e/ou do movimento. O autor explicitou que a base teórica dessa concepção é, principalmente, da psicologia da aprendizagem e da psicologia do desenvolvimento, dando a primeira atenção ao desenvolvimento motor e a segunda ao desenvolvimento cognitivo. 
Em suas considerações indicou que a psicologização da educação é problemática, já que traz a sua despolitização.

Desse modo, ao se posicionar sobre as concepções biologizante e piscologizante da Educação Física, Bracht (1999, p.44-45) as considerou limitadas, na medida em que

permitem ver o objeto [da Educação Física] não como construção social e histórica e, sim como elemento natural e universal, portanto, não histórico, neutro política e ideologicamente, características que marcam, também, a concepção de ciência onde vão sustentar suas propostas.

Por fim, em uma terceira concepção de Educação Física denominada de crítica ou progressista, que é fortemente embasada nos conhecimentos oriundos das ciências humanas e sociais e que possui como categoria importante fazer a crítica do papel da educação na sociedade capitalista, conforme Bracht (1999), tem centralidade as expressões "cultura corporal", "cultura corporal de movimento", ou "cultura de movimento".

Ainda vale destacar que no entendimento do pesquisador a definição do objeto da Educação Física, e desse modo de sua concepção, esta relacionado com o papel social a ela atribuído e que isso é definidor do tipo de conhecimento buscado para sua fundamentação. É importante observar que isso ocorre de modo interdependente, ou seja, o tipo de conhecimento e concepção também define o papel social à área atribuído.

Assim, criada em meio a todos esses processos que atingiram o país e em especial a Educação Física, a Revista Nova Escola traz a veiculação de "mensagens, prescrições, comandos que, embora não sejam assimilados, apropriados e/ou praticados literalmente pelo professor-leitor, possuem a finalidade de transmitir e incutir determinados significados tidos como preferenciais em detrimento de outros" (RAMOS, 2009, p. 26). Contudo, imbuída do ideário de que é possível a participação popular nos diversos temas sociais o periódico abre espaço, entre outras possibilidades, para que as práticas pedagógicas dos professores que atuam no Ensino Infantil e Fundamental, notadamente os de Educação Física, sejam publicadas em suas edições. A partir disso, entendo ser pertinente considerar que o impresso é veículo que possibilita aos professores do Ensino Fundamental a divulgação de suas práticas pedagógicas que são organizadas a partir de suas experiências profissionais cotidianas, intelectuais, de visão de mundo e sociedade. Dessa maneira, passo a olhar de modo mais atento a relação entre a Revista Nova Escola, a Educação e em especial a Educação Física escolar.

Posto isso, procurei nesse artigo analisar quais concepções do componente Educação Física historicamente foram veiculadas pela Revista Nova Escola entre 1986 e 1997. Atrelado a essa intenção busquei, também, observar quais os conteúdos da Educação Física o periódico veiculou; e, verificar se ocorreu, em seu interior, concepções divergentes de Educação Física em relação as orientações que veiculou para a área. Para tanto, utilizei como fontes as reportagens que veicularam sugestões de conteúdos de Educação Física publicadas pelo impresso, assim como as matérias que trouxeram os relatos de práticas pedagógicas de professores da área ${ }^{9}$ publicadas ao longo das 108 edições veiculadas nesses onze anos. O período pesquisado justifica-se pelo fato de que em 1986 ocorre o surgimento do impresso e a partir de 1998 constata-se uma nova orientação na relação Revista Nova Escola e Educação Física ${ }^{10}$.

Considerando que a veiculação de um periódico navega conforme o processo histórico, veiculando/modificando concepções de Educação e Educação Física, parti dos pressupostos da lógica histórica proposta por Thompson (1981) que procura evidenciar, mesmo num único instante, manifestações contraditórias dos fenômenos que estão em movimento, não admite procedimentos autoconfirmadores e compreende a investigação da 
história como processo ou uma desordem racional, devendo-se ter em conta noções de causação, de contradição, de mediação e da organização da vida social, política, econômica e intelectual. Portanto, à luz da interpretação historiográfica thompsoniana, compreendi a Revista Nova Escola como um objeto real, concreto e cognoscível do ponto de vista histórico que enquanto produto material é provisório e passível de mudanças e releituras, dadas as perguntas feitas à evidência, assim como não pode ser apartada do todo social que a envolve e, senão a determina, estabelece relações de tensão permanente. Por fim, entendo ser necessário submetê-la à investigação que desnude as contradições e mediações que revelam dados projetos de organização da vida social.

Assim, entendo que esses procedimentos teórico-metodológicos são pertinentes para compreender a Revista Nova Escola, que teve sua primeira edição lançada em março de 1986 e que já em seu surgimento contou com o apoio do governo federal, por meio do MEC, que subsidiou $70 \%$ de seu custo e garantiu que todas as escolas públicas brasileiras, naquele momento, recebessem um exemplar do impresso de modo gratuito. Contudo, Ramos (2009), Pedroso (1999) e Silveira (2006) atestaram que esse impresso é na verdade a retomada de um projeto da Editora Abril $^{11}$ do ano de 1971, que veiculou a publicação chamada "Escola para Professores", conhecida por Escola, editada entre outubro desse ano a abril de 1974, em que foram publicados vinte e sete números ${ }^{12}$.

Entre 1986 e 1997 a Revista Nova Escola veiculou durante o ano nove edições mensais, sendo que em janeiro, fevereiro e julho, meses de férias escolares, não publicou nenhum número. As tiragens da Revista Nova Escola quase sempre foram expressivas, excetuando-se o período do governo do Presidente Fernando Collor de Mello que interrompeu seu convênio com o MEC o que, na opinião de Ramos (2009, p.51), "resultou na redução drástica da tiragem, de 370 mil para 04 mil, demonstrando a importância do subsídio estatal para que a revista pudesse permanecer "viva'". A renovação do convênio entre o impresso e o MEC, no final de 1992, restringiu o envio de somente um exemplar para cada escola urbana, momento em que o periódico restabeleceu sua antiga tiragem. Já durante o governo de Fernando Henrique Cardoso, que utilizou ostensivamente os meios midiáticos para propagandear suas reformas, a revista teve sua tiragem elevada significativamente.

Ancorado em Silva e Feitosa (2008) percebo que o impresso apresentou etapas em sua evolução, isso em termos de estrutura e de modo especial do fator histórico. Assim os autores destacaram que entre 1986 a 1994, período de inserção do periódico no mercado editorial, "as matérias estavam mais orientadas para o real (deficiências de nossa educação, dificuldades dos professores, etc), do que para o ideal" (SILVA; FEITOSA, 2008, p.185); já entre 1995 a 1997, que coincide com o início do governo de Fernando Henrique Cardoso, o impresso sofreu mudanças que deixaram visualizar seu esforço para se ajustar a nova sensibilidade estética advinda com as novas tecnologias da informação e também pela nova perspectiva das transformações pedagógicas que se iniciaram com as Reformas Educacionais.

Por fim, observando a partir de sua caracterização material e organização interna, é possível perceber que a Revista Nova Escola sofreu alterações, sendo exemplar nesse sentido o fato de ter havido alterações em suas dimensões, de forma que de 1986 a 1989 media $20 \mathrm{~cm}$ por $26 \mathrm{~cm}$ e a partir de 1990 passou a ter dimensão de $20,5 \mathrm{~cm}$ por $27 \mathrm{~cm}$, o que para Ramos (2009) representa a busca do impresso de se assemelhar cada vez mais as outras revistas de consumo. 


\section{Revista Nova Escola: entre sugestões de conteúdo e relatos de práticas pedagógicas}

A Revista Nova Escola, desde março de 1986, adotou como uma das formas de compor suas edições a veiculação de matérias com sugestões de conteúdos para as diferentes disciplinas escolares que, conforme Silveira (2006, p.61), "são explicadas passo a passo 'a fim de facilitar' a vida do professor e tornar suas aulas mais interessantes". O impresso também compõe suas edições com matérias que trazem os relatos das práticas pedagógicas de professores brasileiros, sendo de acordo com Silveira (2006, p.52) uma "estratégia de formação de professor leitor que é a de dar voz e vez aos próprios colegas de profissão, responsáveis por exemplificar o 'como se faz' na sala de aula”. Mas, ao mesmo tempo, não é possível desconsiderar que os relatos de práticas pedagógicas publicados pelo periódico, ainda que registrados por um jornalista (que nem sempre foi identificado no corpo da matéria), constituem de fato descrições de trabalhos que foram desenvolvidos por diversos professores brasileiros do Ensino Fundamental, que foram planejados e executados ancorados em suas experiências acadêmicas, pedagógicas e de visão de mundo.

Porém, é preciso considerar que, entre outros objetivos, o desejo de publicar os relatos de práticas pedagógicas dos professores é um procedimento pretendido pelo criador do impresso, Victor Civita, conforme pode ser observado quando expressou, já no primeiro número, seu desejo de que esta

[...] nossa revista se transforme num elemento de leitura agradável e instrutiva para o professor de $1^{\circ}$ Grau, para o estudante de Pedagogia, de Letras, do Normal e para todos aqueles que, de uma forma ou de outra, estão envolvidos com o processo de Educação no país. Queremos que cada um deles aguarde com ansiedade a chegada de sua revista e que nos escreva sugerindo, criticando, esclarecendo, retificando ou revelando alguma experiência de interesse de seu colega. Esta será a nossa grande recompensa (CIVITA, 1986, p.5).

Assim, observa-se que o impresso desejava colocar o professor como um de seus autores, ser agradável e instrutivo, além de receber notícias sobre experiências pedagógicas, o que certamente foi aceito por seu público visado quando, por exemplo, em 1989 foi divulgada por sua diretora de redação a seguinte mensagem:

\section{Amigos,}

Da capital do Amazonas e de um município do oeste paulista é que nos chegam, neste mês [de setembro], notícias de duas iniciativas imaginosas, capazes de oferecer às crianças e jovens uma dimensão mais larga do que seja a escola e a aventura do aprender (SANCHEZ, 1989, p.3).

E no ano seguinte, no mês de abril, afirmou que

Nem sempre é fácil descobrir onde estão se desenvolvendo essas experiências que queremos mostrar a todos que nos lêem. [...]. Mas muitos educadores já estão nos escrevendo contando sobre o que estão fazendo, e isso tem nos ajudado muito (SANCHEZ, 1990, p.5).

De todo modo, ainda que não seja possível perceber como objetivamente o impresso, entre 1986 a 1997, a partir das notícias que recebeu dos professores, selecionou as práticas pedagógicas que considerou importantes para serem publicadas, é fato que enviou seus repórteres para registrar o trabalho e publicou relatos de práticas pedagógicas 
de docentes das diversas regiões do país, sendo este procedimento um mecanismo que, ao longos de seus primeiros onze anos, constituiu a publicação.

No tocante as reportagens com sugestões de conteúdos e relatos de práticas pedagógicas de professores de Educação Física veiculadas pela revista, constatei, como apresentarei a seguir, que entre 1986 a 1997, foram publicadas, respectivamente, 12 e 14 matérias ${ }^{13}$.

\section{Sugestões de conteúdos da Revista Nova Escola: educação pelo movimento}

Como mencionado anteriormente, a Revista Nova Escola, entre 1986 e 1997, veiculou 12 matérias que trouxeram sugestões de conteúdos para a disciplina Educação Física. A tabela 1 a seguir apresenta os conteúdos sugeridos pelo impresso.

Tabela 1 - Conteúdos sugeridos pela Revista Nova Escola entre 1986 e 1997

\begin{tabular}{c|c}
\hline Conteúdos & Número de matérias \\
\hline Esporte & 1 \\
\hline Jogo e brincadeira & 9 \\
\hline outros* & 2 \\
\hline TOTAL & $\mathbf{1 2}$ \\
\hline
\end{tabular}

Fonte: Elaborado com base nas edições da Revista Nova Escola com reportagens sobre Educação Física publicadas entre 1986 a 1997

* Classifiquei como outros os conteúdos que não compõem o que comumente vem sendo abordado nas aulas de Educação Física escolar. Assim, no caso das sugestões dessa fase da revista, são os exercícios físicos para dramatizar.

Considero importante ressaltar que o periódico, ao sugerir os conteúdos para a área, não identificou, em algumas reportagens ${ }^{14}$, nenhum professor ou equipe pedagógica que tenha atuado na sua elaboração, fato que pode ser explicado se for levado em conta que o criador do impresso o anunciou como o "[...] resultado de um velho sonho e de um longo trabalho de uma equipe de experimentados jornalistas e profissionais da Educação" (CIVITA, 1986, p.5), o que indica que a publicação possuía compondo seus quadros funcionários com conhecimento na área pedagógica para a tarefa de sugerir conteúdos. Mas, também levando em consideração que na maioria das matérias o impresso divulgou os professores ou equipes pedagógicas que formularam as sugestões de conteúdos é possível inferir que o periódico utilizou este procedimento como um meio de se aproximar de professores e equipes pedagógicas capazes desta tarefa, como forma para se fazer um veículo que possui identificação com seu público de leitores visados e, ao mesmo tempo, como um mecanismo para se constituir uma revista que possui credibilidade para sugerir conteúdos no âmbito da Educação Física.

Assim, conforme pode ser observado na tabela 1, é possível constatar que o conteúdo jogo e brincadeira foi o mais sugerido pelo periódico. Dessa maneira, em 1988, no mês de maio, o impresso divulgou matéria em que trouxe três atividades sugeridas pela equipe técnica de Educação Física da Coordenadoria de Estudos e Normas Pedagógicas da Secretaria de Educação de São Paulo (CENP), recomendadas para alunos da $1^{\mathrm{a}}$ e $2^{\mathrm{a}}$ séries. Os jogos sugeridos foram o esconde-esconde, bola atrás e o gato e o rato que podem, de acordo com o periódico, possibilitar um bom desenvolvimento motor, afetivo e social. A revista, para a realização das atividades, fez uma lista de indicações, tais como: para que o professor não apresentasse todas as regras dessas brincadeiras, já que a maioria dos alunos já sabiam como joga-las e que fosse respeitado o conhecimento adquirido fora da escola, deixando que os próprios alunos explicassem os jogos para os que não os conheciam; para que incentivasse os estudantes a se organizarem sozinhos, discutindo e estabelecendo 
regras, de forma que a função do professor no decorrer das brincadeiras fosse "o de mediador, dando explicações quando lhes forem exigidas e estimulando o aluno a refletir sobre o que está fazendo e a buscar consertar os erros" (APOSTE..., 1988, p.20). Além dessas, ainda recomendou ao professor que na realização das atividades fizesse com que meninos e meninas brincassem juntos, pois favoreceria o desenvolvimento social.

No mês seguinte, o impresso publicou uma reportagem em que propôs o uso do jogo da amarelinha nas aulas de Educação Física seguindo a sugestão da CENP devido ao fato de ser uma atividade útil para crianças de $1^{\mathrm{a}}$ a $4^{\mathrm{a}}$ série. O periódico asseverou que

Por se tratar de uma atividade do cotidiano da criança, a amarelinha também facilita a aprendizagem de noções abstratas de Matemática nas primeiras quatro séries. A vantagem é que essa aprendizagem ocorre sem que os alunos tenham de memorizar mecanicamente os conceitos, segundo uma pesquisa realizada em uma favela de Campinas (SP), em 1984, pelas professoras Maria de Lurdes Menon e Maria Cardillo." (VAMOS..., 1988, p.22).

A revista nesta matéria informou que os benefícios da realização do jogo da amarelinha na Educação Física são: favorecer o desenvolvimento da noção espacial, definição dos lados de utilização dos membros corporais, desenvolve equilíbrio e força nos membros inferiores. Para a disciplina Matemática, seguiu informando que o jogo favorece o uso de expressões que estão relacionadas a seus conteúdos, tais como: quadrado, risca, par e impar. Assim, foi sugerido que se trabalhasse, por meio de indagações, conteúdos matemáticos como: interior, exterior e fronteira; identificação de retas, paralelas e ângulos retos; relação entre quadriláteros e retângulos.

Em 1989, no mês de maio, a Revista Nova Escola publicou uma reportagem, em que seguindo as recomendações da CENP, sugeriu a utilização de jogos com cordas para desenvolver os aspectos motor, afetivo e social nas aulas de Educação Física para alunos da $1^{a}$ série. Os jogos sugeridos pelo periódico foram o equilibrista, corrida de estafetas e saltar ou pisar o rabo da cobra, e segundo o impresso, o primeiro desenvolve o equilíbrio corporal, o estímulo ao trabalho coletivo, representação de figuras e conceitos de figuras geométricas; o segundo possibilita desenvolver o relacionamento em grupo e coordenação espaço-temporal; e, o terceiro traz como benefício o desenvolvimento da coordenação motora fina, flexibilidade nas mãos e coordenação espaço-temporal.

A revista, nesta reportagem, recomendou aos professores leitores que aproveitassem o interesse das crianças e propusessem sua realização, pois "Além de se divertir, seus alunos terão muitas vantagens, principalmente no que se refere ao desenvolvimento motor, afetivo e social" (DÊ CORDA..., 1989, p.20). Contudo, os professores foram alertados para não impor nada e que respeitassem o conhecimento que os alunos adquirem fora da escola, deixando-os se organizarem de forma livre e discutirem entre si as regras dos jogos que, inclusive, sofre variação de região para região do país. Desse modo, para o impresso, conforme divulgou nessa matéria, "preferencialmente, o professor deve estimular os alunos a refletirem sobre os erros que cometem e a tentarem sempre superar as dificuldades" (DÊ CORDA..., 1989, p.20).

Também em 1989, no mês de outubro, o periódico, seguindo as recomendações da CENP, veiculou reportagem que trouxe a sugestão de jogos com bola para alunos de $1^{\mathrm{a}}$ a $5^{\mathrm{a}}$ série. Assim, nesta matéria, o impresso reconheceu que a atividade possui bastante força em nossa cultura, ainda que esteja sempre associada ao futebol que se destina na maioria das vezes aos garotos. No entanto, a partir da consultoria da CENP, sugeriu quatro atividades com bola para os dois sexos. Para as turmas de $1^{\mathrm{a}}$ e $2^{\mathrm{a}}$ séries o periódico indicou 
o jogo bola ao alvo e uma variação, já para as turmas de $3^{\mathrm{a}}, 4^{\mathrm{a}}$ e $5^{\mathrm{a}}$ séries recomendou os jogos futebol aos pares, bola à torre e bola ao ar. A revista explicitou que para os alunos mais novos as atividades favorecem o resgate do brinquedo popular, ajudando no desenvolvimento motor, cognitivo, social e afetivo, enquanto que para os alunos de maior faixa etária os jogos têm sua importância por possibilitar a construção de regras pelos próprios estudantes, sendo, dessa maneira, um bom exercício para desenvolver autonomia e cooperação. Conforme o impresso, para conseguir desenvolver esses elementos, é necessário existir um espaço destinado a discussão entre professores e alunos, de forma que não se imponha pacotes com regras, técnicas e táticas (JOGOS..., 1989).

Diante disso, constatei que o conteúdo jogo e brincadeira, além de ser o que possuiu mais matérias o veiculando, foi predominantemente sugerido para as turmas de $1^{\mathrm{a}}$ a $4^{\mathrm{a}}$ séries do Ensino Fundamental. Ficou evidente a presença da CENP nos primeiros anos de circulação do impresso, sugerindo ou opinando sobre o conteúdo. Assim, ao propor este conteúdo a Revista Nova Escola recomendou a promoção de atividades que enfatizassem a cooperação entre os alunos, fomentassem a criação de regras e incentivassem a participação de meninos e meninas durante as aulas. É possível perceber, ainda, que o impresso recomendou que o professor leitor desenvolvesse em seus alunos os aspectos motor, cognitivo, social e afetivo, por meio das atividades sugeridas; além de promover a relação no ensino do conteúdo jogo na Educação Física com o aprendizado de conceitos da Matemática.

Desse modo, levando em conta que o jogo obteve, entre 1986 e 1997, na Revista Nova Escola um espaço de destaque, sendo inclusive recomendado ao professor leitor como se portar e o que procurar desenvolver em seus alunos, fica evidente que o impresso não compactuou com o modelo esportivizante de Educação Física, que foi tão questionado durante a década de 1980. O próprio periódico, no ano de 1990, na edição 42 publicada em setembro, trouxe a disciplina Educação Física para ser o tema principal de sua capa ${ }^{15}$, conforme pode ser observado na figura 1 a seguir.

Figura 1 - Capa da Revista Nova Escola em que a disciplina Educação Física é o tema principal

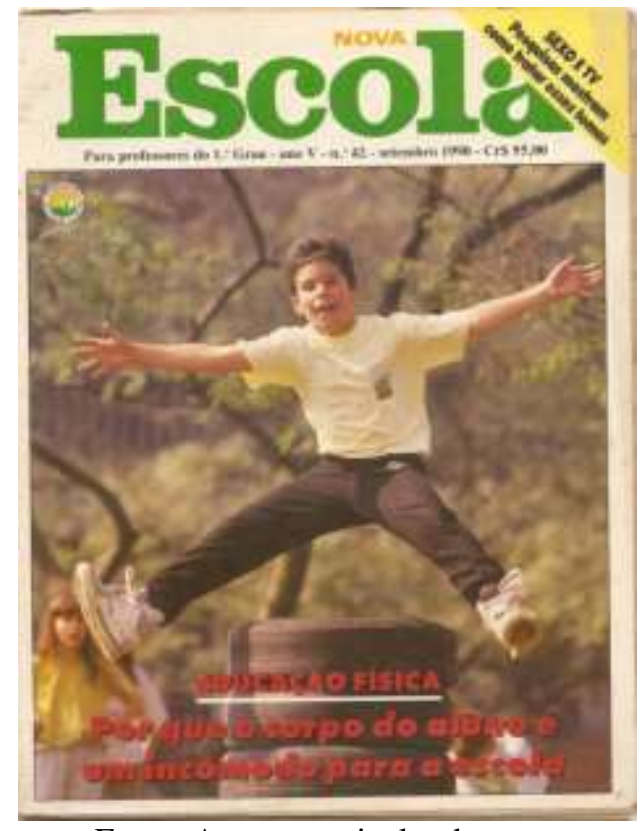

Fonte: Acervo particular do autor 
A reportagem deste número veiculou a opinião de Celi Taffarel, Mauro Betti, José Guilmar Mariz de Oliveira e depoimentos de professores de escolas públicas que denunciavam a situação da instituição e da Educação Física, principalmente a ofertada para alunos de $1^{\mathrm{a}}$ a $4^{\mathrm{a}}$ séries, que, entre outras dificuldades, tinham suas aulas sendo ministradas por professores regentes. Na matéria desta edição da revista, além da denúncia, também foi declarado que o modelo esportivizante da área e o exercício físico como um fim em si mesmo vinham sendo questionados e foram publicadas as opiniões dos professores Mauro Betti, José Guilmar Mariz de Oliveira, Go Tani e João Batista Freire sobre as finalidades da Educação Física, tendo os dois últimos estudiosos maior espaço.

Assim, foi descrito na reportagem sobre a existência de estudos, mundialmente confirmados, que caracterizam as fases de desenvolvimento da motricidade em:

fase dos reflexos automáticos (pegar, sugar), que vai até aproximadamente 1 ano de idade; fase dos movimentos rudimentares, que vai até os 2 anos, quando a criança começa a tomar consciência do movimento, engatinha e anda; fase dos movimentos fundamentais, que vai dos 2 aos 7 anos, quando se desenvolvem em níveis de complexidade crescentes habilidades como correr, saltar, bater, rebater, trepar, suspender, arremessar etc.; e fase de movimentos relacionados ao esporte, que vai até os 14 anos, e que pode ser subdivididas nos estágios transitório, específico e especializado, quando devem ser exploradas combinações de movimentos, como preparação final para o esporte específico, dança ou lazer (FRARE et al, 1990, p.16).

Em seguida, houve destaque para a opinião do professor Go $\mathrm{Tani}^{16}$, da Universidade de São Paulo (USP), para confirmar que a Educação Física não está trabalhando de modo a contemplar esse repertório de movimentos, criticar a forma repetitiva e mecânica como os exercícios são realizados, como também, a iniciação desportiva precoce, que limita e impõe um padrão de movimento que restringe o desenvolvimento motor. Assim, seguiu a reportagem do periódico informando que para o professor da USP, o ideal é que entre os 6 aos 12 anos a criança possa combinar os movimentos básicos, de diversas maneiras em sequências que sejam cada vez mais complexas, tendo em conta que esses conhecimentos serão a base em que vão se estruturar as habilidades específicas necessárias para o trabalho, lazer, vida social e esportiva. Foi declarado na matéria pelos repórteres do impresso que

Do ponto de vista dessa concepção, é extremamente importante que o professor de Educação Física entenda bem o que é a criança, como ela se move, como aprende, como se desenvolve e como manifesta suas emoções e sentimentos. É em função dessas características que ele vai estabelecer o objetivo, o conteúdo e o método de ensino (FRARE et al, 1990, p.17).

Ainda foi destacada a fala do pesquisador da USP que afirmou que o professor sempre deve em sua prática observar o estágio de desenvolvimento motor da criança, para melhorar a qualidade e o controle do movimento, além de que ao propor exercícios para os alunos é necessário ter consciência de seus significados e dos objetivos que busca atingir.

Também foi destacado na reportagem o depoimento de João Batista Freire ${ }^{17}$ que lembrou ser preciso, na Educação Física, além da exercitação de sentimentos e habilidades motoras, que se propicie espaço para a criatividade, alegria e lazer, de forma que a aula 
seja prazerosa, sendo importante na busca desses elementos as brincadeiras e os jogos. Assim, os jornalistas do periódico indicaram que

João Batista acha que os jogos e brincadeiras são o melhor instrumento para se atingir o que ele considera os objetivos da Educação Física no $1^{\circ}$ Grau: partir do conhecimento corporal já adquirido pela criança para aprimorar suas habilidades motoras, desenvolvendo ao mesmo tempo os aspectos intelectual e sentimental e as relações sociais (FRARE et al, 1990, p.18).

Desse modo, conforme descrito nessa reportagem do impresso, essas novas concepções demandam dos professores, seja os de Educação Física, ou os de $1^{\circ} \mathrm{Grau}$ menor que assumem as aulas, bastante e diversificados conhecimentos, que no entendimento de Go Tani não estão sendo ofertados pelas Universidades. Por fim, foi asseverado na matéria que

Os professores e especialistas defensores da 'educação de corpo inteiro' exigem outra mudança, ao mesmo tempo administrativa e pedagógica: uma definição clara e urgente da Educação Física como área de conhecimento científico e não como mera atividade (FRARE et al, 1990, p.18).

Assim, entendo ser possível notar que o impresso procurou participar do debate que estava ocorrendo na Educação Física desde o início dos anos 1980, reproduzindo inclusive a ambiguidade constatada por Caparroz (1997) sobre o fato da área em alguns momentos ter sido tratada, pela literatura da década de 1980, como prática social e em outros como campo de interesse científico. Também o impresso deixou claro sua opção por uma orientação que não coadunava com a perspectiva esportivizante, mas também procurou fazer o professor leitor entender que a "educação de corpo inteiro", perspectiva adotada por João Batista Freire, era consenso entre todos os entrevistados, homogeneizando, desse modo, posições que não eram exatamente iguais em relação a área e veiculando sugestões de conteúdos e atividades que se relacionassem a tal perspectiva.

Portanto, compreendo que a Revista Nova Escola, ao sugerir conteúdos e atividades de Educação Física aos seus leitores no período compreendido entre 1986 e 1997, possuiu marcadamente uma orientação que converge para a educação pelo movimento, em que o jogo tem predomínio, é utilizado para o aprendizado de conhecimentos de outras disciplinas escolares e ensinado, principalmente, na primeira fase do Ensino Fundamental, o que possibilita compreender que o periódico veiculou uma concepção psicologizante de Educação Física (BRACHT, 1999).

\section{Relatos de práticas pedagógicas dos professores de Educação Física veiculados pela Revista Nova Escola: adesão dos docentes à educação pelo movimento}

A Revista Nova Escola veiculou, entre 1986 e 1997, 14 matérias que relataram as práticas pedagógicas de professores de Educação Física do país ${ }^{18}$. A tabela 2 a seguir apresenta os conteúdos que foram trabalhados pelos professores de Educação Física nos relatos veiculados pelo impresso. 
Tabela 2 - Conteúdos presentes nos relatos de práticas pedagógicas veiculados pela Revista Nova Escola entre 1986 e 1997.

\begin{tabular}{c|c}
\hline Conteúdos & $\begin{array}{c}\text { Número de relatos de práticas pedagógicas em que } \\
\text { está presente }\end{array}$ \\
\hline Atividade Física e saúde & 01 \\
\hline Dança & 05 \\
\hline Esporte & 02 \\
\hline Exercícios Físicos* & 02 \\
\hline Ginástica & 04 \\
\hline Jogo e brincadeira & 17 \\
\hline Luta & 01 \\
\hline Outros** & 04 \\
\hline
\end{tabular}

Fonte: Elaborado com base nas edições da Revista Nova Escola com reportagens sobre Educação Física publicadas entre 1986 a 1997

* caminhadas, corridas e saltos.

* *Classifiquei como outros os conteúdos que não compõem o que comumente vem sendo abordado nas aulas de Educação Física escolar. Assim, no caso dos relatos de práticas pedagógicas dessa fase da revista, são os que utilizaram as práticas corporais como meio de relacionar homem e natureza; Tai Chi Chuan; Gincana; e atividades aquáticas.

Antes de dirigir a atenção para os relatos de práticas pedagógicas dos professores de Educação Física veiculados pelo periódico entre 1986 e 1997, considero adequado fazer algumas considerações. Assim, foi possível verificar que 13 escolas públicas, localizadas nas regiões Sudeste, Centro-Oeste, Norte e Nordeste, foram identificadas como locais em que os professores trabalhavam e desenvolveram as práticas pedagógicas relatadas pelo periódico. No entanto, apenas 01 escola particular, localizada na região Sudeste, foi identificada como local de trabalho do professor onde foi desenvolvida a prática pedagógica veiculada pela revista.

Esse dado permite constatar que a maioria das práticas pedagógicas publicadas no impresso em que se identificou a dependência administrativa da escola, nesse período, foram realizadas por professores de Educação Física que trabalhavam na rede pública de educação, seja municipal, estadual ou federal, em diferentes regiões do Brasil, o que pode ser explicado tendo em vista o fato do periódico, desde seu surgimento, ter sido distribuído gratuitamente nas escolas públicas, mediante convênio com o MEC, o que favoreceu que fosse bastante conhecido do professorado e com esta categoria profissional criasse uma relação de identificação. Também, levando em conta a observação de Pedroso (1999) sobre a ausência de canais de informação entre os professores e os órgãos ligados a política educacional é admissível considerar que o impresso procurou tornar-se uma via para o professor manifestar sua opinião. Contudo, não é possível deixar de admitir que os professores de Educação Física brasileiros que trabalhavam na escola pública naquele momento, ao decidirem enviar notícias sobre suas práticas pedagógicas para a Revista Nova Escola, usaram o impresso como veículo para divulgar seus trabalhos.

Feitas estas considerações passarei a analisar os relatos de práticas pedagógicas de professores de Educação Física do Ensino Básico veiculados pela Revista Nova Escola. Desse modo, conforme pode ser observado na tabela 2, o conteúdo jogo e brincadeira foi o que esteve presente no maior número de relatos de práticas pedagógicas. Assim, em setembro de 1993, o periódico veiculou uma reportagem em que relatou a prática pedagógica do professor da Escola Municipal de Primeiro Grau Padre Leão Vallerié, em Campinas, São Paulo, que utilizou brincadeiras de rua em suas aulas, com alunos de $1^{\mathrm{a}}$ e $2^{\mathrm{a}}$ séries. Usando bastões, cordas e bolas o professor, em conjunto com os alunos, decidiram quais foram as atividades realizadas. Dessa maneira, um jogo trabalhado foi o pega-pega 
na corrente, variação do pega-pega, em que alunos e professor demarcaram o espaço de jogo, decidiram quem seria o pegador e formularam as regras (A PEDAGOGIA...,1993).

No decorrer das aulas, com a entrada das brincadeiras populares na rotina dos alunos, o professor, conforme veiculado na reportagem, introduziu novos elementos para enriquecer o processo de aprendizagem. Assim, houve a sugestão de regras mais difíceis para os jogos e variação nos materiais utilizados, de forma que

O esconde-esconde em duplas, por exemplo, é uma novidade para os alunos da $2^{\mathrm{a}}$ série. Bastões de vários tamanhos são incorporados aos jogos para ajudar a passar a noção de seriação e classificação. Bolas de meias pequenas - algumas leves, outras pesadas - facilitam a demonstração de que nem tudo que é grande é pesado (A PEDAGOGIA..., 1993, p.38).

De acordo com o professor de Campinas, em relato nessa matéria da revista, a incorporação de novas regras, jogos e materiais para terem sentido devem vincular-se à vivência corporal dos estudantes e considerou que na $1^{\text {a }}$ série as atividades oferecidas deveriam gerar um grande número de oportunidades para os alunos experimentarem movimentos e conhecerem seu próprio corpo, enquanto na $2^{\mathrm{a}}$ série necessitariam ser destacados a construção e o respeitos às regras, como também, a resolução de problemas. O docente ainda apontou como vantagem da utilização das brincadeiras de rua nas aulas a possibilidade de preservação dessas atividades, tendo em vista o processo de urbanização e a competição da televisão e dos videogames. As atividades foram realizadas na quadra da escola e na área de recreação do bosque municipal, que fica situado ao lado do prédio escolar.

Foi declarado pelo periódico que para o docente a competição não deve se constituir uma finalidade da Educação Física, "mas uma etapa de aprendizagem introduzida aos poucos, para propiciar ao aluno condições de conhecer novos movimentos" (A PEDAGOGIA..., 1993, p.38). Por fim, foi enfatizado que o professor da Escola Municipal de Primeiro Grau Padre Leão Vallerié procurou, na medida do possível, integrar sua disciplina com outras áreas do conhecimento.

Em setembro de 1995 a Revista Nova Escola relatou que na Escola Municipal de Primeiro Grau Narcisa Amália, na Ilha de Guaratiba, região rural do estado do Rio de Janeiro, havia alunos que na fase de alfabetização não tiveram contato com lápis ou livro e estavam manuseando pela primeira vez uma folha de papel. Informou que a taxa de reprovação no primeiro ano era de $60 \%$, configurando um péssimo desempenho que os estudantes costumavam ter e que para alterar esse panorama a escola enfrentou

[...] as limitações de seus alunos exercitando tanto o cérebro quanto os músculos das crianças. É o programa Educação pelo Movimento, que se baseia nos princípios da psicocinética, uma proposta que usa os movimentos físicos para desenvolver as funções motoras, psicomotoras, e mentais dos alunos. Trocando em miúdos, a intenção da escola é usar brincadeiras e jogos da Educação Física para passar as habilidades requeridas pelo início da alfabetização (PARA..., 1995, p.40).

De acordo com o diagnóstico do professor de Educação Física da escola Narcisa Amália, publicado nessa reportagem da revista, a falta de noção de si mesmas, do espaço, do tempo, da dimensão e da lateralidade são um dos grandes problemas desses alunos. Com isso, foi ressaltado no periódico que o professor de Educação Física era o responsável pelo desenvolvimento do programa para os demais professores e que ele propôs "aos 
alunos brincadeiras e jogos simples, mas que pretendem atacar diretamente suas deficiências" (PARA..., 1995, p.40).

O professor da escola Narcisa Amália, segundo relato publicado na matéria do impresso, para realizar suas atividades usou o bosque que fica em frente à escola. Assim, desenvolveu atividades que pretendiam determinar a capacidade auditiva dos alunos, já que entendia haver dificuldade de aprendizagem porque os estudantes não diferenciavam adequadamente os sons. Desse modo, foi descrita a tarefa em que os alunos foram convidados a ficarem em silêncio para ouvir os sons do bosque e em seguida contarem o que ouviram. No desencadeamento da aula o professor questionou sobre de que lado os sons vieram, se da direita ou esquerda. Em outro momento convidou os alunos a imitarem as árvores ficando de pé e esticando os braços para o alto; em seguida incitou as crianças a se abaixarem, imitando o mato rasteiro. Com isso, conforme descrito na reportagem, o professor da Ilha de Guaratiba questionou de modo provocativo como seria possível um aluno desenhar uma letra, se não consegue identificar o que seja lado direito ou esquerdo?

Por fim, foi registrado que o trabalho apresentou dois módulos. O primeiro consistiu em encontros semanais, em que o professor apresentou os fundamentos teóricos da proposta aos outros docentes; ouvia de seus colegas uma narrativa das dificuldades das salas; e, realizou as atividades com os estudantes sob a observação dos demais professores. No segundo, os jogos e brincadeiras foram realizados buscando responder especificamente aos problemas levantados pelos outros professores (PARA..., 1995).

Em 1996, no mês de dezembro, a Revista Nova Escola publicou reportagem em que fez o relato da prática pedagógica do professor de Educação Física da Escola Municipal Leda Vargas Gianerini, em São Gonçalo, no Rio de Janeiro. É interessante destacar que, mesmo com o título da reportagem trazendo a informação para o professor leitor de que a prática se relacionava com o ensino da ginástica, o subtítulo da matéria ofereceu, de forma mais fidedigna, informação sobre o que de fato o professor fluminense trabalhou em sua aula, citando inclusive que foi uma iniciativa que recebeu premiação no ano de 1995 em concurso realizado pelo MEC em conjunto com a Fundação Moinho Santista. Com isso, foi mencionado que "Professor de Educação Física de São Gonçalo, no Rio de Janeiro, usa brincadeiras infantis tradicionais para auxiliar no ensino de Matemática e Português" (GINÁSTICA..., 1996, p.16).

Desse modo, conforme a opinião do professor de São Gonçalo publicada nessa reportagem, é útil no processo de alfabetização usar braços, pernas, pular, rolar no chão, lançar bolas, sendo dessa maneira um desperdício a aprendizagem da leitura e escrita unicamente utilizando cérebro, lápis e papel. Assim, foi relatado que em suas aulas o docente apresentou conceitos elementares de Português e Matemática para os alunos e realizou exercícios que podiam auxiliar a afinar os movimentos que são utilizados no ato da escrita (GINÁSTICA..., 1996).

Foi descrito que o professor também considerou que a Educação Física é essencialmente interdisciplinar, sendo o ato de aprender a escrever e das operações da Matemática não somente conseguida por meio de um código verbal. Nesse sentido, foi descrito na reportagem do periódico que o docente propôs "que se desenvolva a 'alfabetização corporal', ou seja, que se aproveite o interesse das crianças por atividades físicas para apresentar temas que elas ainda não conhecem" (GINÁSTICA..., 1996, p.16). Em relação ao planejamento das atividades, foi divulgado pelo impresso que era realizado em um trabalho conjunto com os professores de Português e Matemática, de forma que o docente de Educação Física partia dos jogos e brincadeiras que as crianças já conheciam.

Assim, foram apresentadas três brincadeiras tradicionais realizadas pelo professor da Escola Municipal Leda Vargas Gianerini para desenvolver a "alfabetização corporal”. A 
primeira foi a amarelinha, que após a descrição de como ser realizada foi explicitado que "é preciso [durante sua realização] abaixar-se sem encostar um dos pés no chão, rodopiar no ar, calcular distâncias e até fazer contas" (GINÁSTICA..., 1996, p.18), o que, para o docente, conforme opinião relatada na reportagem, desenvolve a coordenação espaçotemporal, agilidade e lateralidade que são habilidades necessárias para se aprender a escrever. Também foi descrito que o professor utilizou problemas de Matemática para serem resolvidos durante o jogo. A segunda atividade foi o pique-corrente, variação do pega-pega, que depois de ser explicada a forma de execução teve como justificativa para sua utilização na aula o fato de ser "uma boa oportunidade de visualizar operações matemáticas simples: enquanto aumenta o grupo dos pegadores, o grupo dos que fogem deles diminui na mesma proporção. A brincadeira serve ainda para passar noções sobre conjuntos" (GINÁSTICA..., 1996, p.17). Foi informado na matéria que, para o professor, correr de mãos dadas necessita uma boa coordenação entre os participantes sendo, assim, um excelente exercício de equilíbrio. E finalizando, houve a brincadeira do elástico que favorece o aprendizado de Português e Matemática.

Assim, entendo que os relatos das práticas pedagógicas anteriormente mencionadas permitem inferir que o periódico, na composição das matérias com os relatos de práticas pedagógicas de Educação Física, concedeu espaço aos professores que desenvolveram um trabalho convergente com as orientações que sugeriu para a área, qual seja, a da educação pelo movimento própria de uma concepção psicologizante, que por meio das práticas corporais pretende que os alunos desenvolvam a sociabilidade, os aspectos motores e cognitivos, além de servir como meio para o aprendizado, sobretudo, das noções de Matemáticas e da Língua Portuguesa. Por outro lado, não se pode eclipsar que esses professores de Educação Física, ao realizarem suas práticas pedagógicas pautadas na educação pelo movimento, estavam atentos a essa perspectiva da área, que foi consubstanciada e dominante no âmbito do Colégio Brasileiro de Ciências do Esporte $(\mathrm{CBCE})^{19}$ entre 1985 a 1989 (PAIVA, 1994), e as realizaram amparados em suas experiências acadêmicas, profissionais e de visão de mundo.

\section{Relatos de práticas pedagógicas dos professores de Educação Física veiculados pela Revista Nova Escola: para além da educação pelo movimento}

Entre 1986 e 1997 também foi possível verificar que a Revista Nova Escola publicou relatos de práticas pedagógicas que tematizaram diferentes conteúdos e que não corresponderam pari passu às orientações educacionais que veiculou para a Educação Física no período. Desse modo, em outubro de 1988, o impresso veiculou matéria em que apresentou o relato da prática pedagógica do professor do Colégio de Aplicação da Universidade Federal de Pernambuco, desenvolvido por meio do projeto o Homem e a natureza, realizado com alunos da $8^{\mathrm{a}}$ série. Assim, foi indicado pelo jornalista do periódico que se tratava de "uma visão inovadora da Educação Física, onde os jovens aprendem desde o respeito ao meio ambiente até a sobrevivência em grupo, substituindo a competição das quadras pela cooperação mútua" (GOMES, 1988, p.30).

Um dos elementos que o docente procurou enfatizar foi a realização de aulas formadas com turmas mistas, em que meninos e meninas estivessem juntos. Além desse aspecto, foi descrito que o planejamento foi realizado com a participação dos estudantes, em que "Tudo começa numa reunião em sala. Os alunos têm nesse momento, amplo espaço para manifestar seus interesses e suas dúvidas. $\mathrm{O}$ grupo avalia as atividades que 
gostaria de pôr em prática e planeja a execução em todos os detalhes" (GOMES, 1988, p.30-31).

Em seu projeto, o professor pernambucano, de acordo com o descrito na reportagem do impresso, preocupou-se em fazer com que os alunos não se limitassem a serem espectadores da natureza e para isso procurou estimular o interesse da turma pela botânica e pela fauna, cobrando relatórios da experiência realizada. A atividade iniciou com a reunião dos alunos no Colégio de Aplicação e caminhada até a mata que fica próxima a escola para, depois, pegarem uma balsa que passa no rio Capibaribe. Em seguida, durante o trajeto na embarcação, o docente dividiu a turma em dois grupos, sendo um responsável pela exploração da mata, identificando plantas venenosas e animais peçonhentos, enquanto o outro simulou uma operação de resgate utilizando como ferramentas materiais encontrados na própria mata. E na aula posterior a turma redigiu um relatório sobre as experiências realizadas (GOMES, 1988). Conforme o professor, em opinião veiculada na reportagem, o projeto pautou-se em seu olhar sobre o mundo em que a cooperação deve ser enfatizada. Na matéria da revista foi informado por seu repórter que as aulas do docente possuíam um conteúdo programático básico, qual seja:

- Vivências de movimentos naturais e desafiados pelo meio ecológico;

- Relatos de textos sobre experiências semelhantes;

- Elaboração de painéis e esquemas de situações vivenciadas;

- Idealização de projetos;

- Atividades de aplicação e dramatização;

- Experimentação e reflexão coletivas (GOMES, 1988, p.33).

É interessante salientar que a leitura do relato dessa prática pedagógica do professor de Colégio de Aplicação da Universidade Federal de Pernambuco veiculada pela Revista Nova Escola foi sugerida pelo Coletivo de Autores (1992, p.63) por apresentar interessantes atividades relacionadas ao excursionismo/acampamento, possuindo conteúdos que direcionam a percepção do aluno para "[...] a necessidade de solução de um problema nele[s] implícito".

E em 1991, no mês de dezembro, o Colégio de Aplicação da Universidade Federal de Pernambuco novamente apareceu nas páginas da Revista Nova Escola. Nesse momento, foi veiculada reportagem que destacou o trabalho de um professor e uma professora de Educação Física da instituição que foi descrita pelo jornalista do periódico como "[...] uma espécie de campo de experimentação para pesquisas de professores em especialização ou mestrado e [que] vem obtendo bons resultados também na área de Educação Física" (TIGRE, 1991, p.44).

Assim, foi informado na matéria que os professores desde 1988, estavam desenvolvendo uma pesquisa, que mesmo antes de seu término indicou mudanças substanciais na atitude dos estudantes e docentes. Nas aulas, alunos de $5^{\text {a }}$ a $7^{\text {a }}$ séries participaram e discutiram de forma coletiva sobre o planejamento das atividades, não havendo, desse modo, professores que determinassem o quê e como eles iriam fazer e os docentes, em sua proposta, abordaram de forma "nova a metodologia de trabalho e estudo, questionando a concepção e a prática habituais da Educação Física" (TIGRE, 1991, p.44).

Conforme publicado na matéria da revista, entre 1988 a 1991, os professores de Educação Física e alunos do Colégio de Aplicação descobriram novas maneiras de praticar esportes e exercícios físicos tradicionais e vivenciaram a disciplina em parques, praças e praias, sendo, também, concedida a possibilidade para que os alunos trouxessem da rua várias informações sobre jogos e danças populares que passaram a ser temas de pesquisa no decorrer das aulas. Foi relatado, ainda, que os professores realizaram uma série de 
modificações na disciplina, assim, iniciaram pela formação de turmas mistas, com meninos e meninas juntos, de forma que a divisão da classe ocorreu por série; favoreceram a criatividade dos estudantes na medida em que os estimularam a criar novas formas de movimento e relacioná-los com o movimento cotidiano de cada um. Em relação as temáticas que compuseram o programa de Educação Física foi informado que haviam atividades aquáticas, jogos, danças e ginástica; e entre os espaços utilizados estavam o pátio do Colégio de Aplicação e uma sala no núcleo de Educação Física da Universidade. Em relação a dinâmica de cada aula foi relatado que nos primeiros 10 minutos os alunos conversavam entre si a respeito dos movimentos que usavam no cotidiano, tanto em jogos esportivos, quanto em caminhadas; em seguida, dividiam-se em grupos de cinco para compor oficinas de salto, corrida, equilíbrio, ou outra atividade que escolhessem. Em um segundo momento, após o planejamento dos exercícios e sua execução em quadra, os grupos se apresentaram para toda a turma. E no término da aula, os alunos sentaram-se no chão, em círculo, para comentar suas experiências e a dos demais colegas (TIGRE, 1991).

Conforme descrito no impresso, os professores além da realização da prática também estimularam que os estudantes realizassem pesquisas a respeito do tema trabalhado, o que ocorreu, por exemplo, com os elementos da cultura nordestina, tais como as festas juninas e as danças. Foi asseverado na reportagem que o professor de Educação Física do Colégio de Aplicação, a partir da pesquisa para a construção de sua tese "[...] chegou à conclusão de que falta nos currículos da disciplina a cultura corporal nordestina. Em geral, esses currículos só acolhem os jogos institucionalizados - futebol, basquete, handebol, vôlei etc" (TIGRE, 1991, p.45).

Ainda, foi veiculado na matéria que os jogos institucionalizados ganharam um novo enfoque, na medida em que os professores do Colégio de Aplicação fizeram com que os alunos questionassem as regras preestabelecidas. Assim, a partir do relato da professora o repórter do impresso afirmou que "[...] é importante o aluno perceber que as regras incidem sobre ele. Portanto, também ele deve atuar sobre as regras, analisando se as condições impostas são compatíveis com a capacidade de cada um" (TIGRE, 1991, p.45).

Desse modo, esses dois relatos publicados permitem inferir que o periódico foi utilizado por esses professores, entre 1986 e 1997, para divulgar práticas pedagógicas que não corresponderam às orientações que a revista veiculou para a Educação Física, sobretudo nas reportagens com sugestões de conteúdos. Também traz à cena, especificamente na matéria veiculada em dezembro de 1991, uma perspectiva para a área que a entende como disciplina curricular que deve tematizar a Cultura Corporal, termo que conforme Bracht (1999) tem centralidade numa concepção crítica ou progressista de Educação Física. De todo modo, deve ser levado em consideração que os dois relatos de práticas pedagógicas se referiram a trabalhos que foram realizados por professores do Colégio de Aplicação da Universidade Federal de Pernambuco, que possivelmente mantinham proximidade com professores do Departamento de Educação Física daquela instituição, e por sua vez possuía, notadamente em 1989, a professora Celi Taffarel, que era docente do referido Departamento de Educação Física, como presidente do CBCE, que naquele momento, de acordo com Paiva (1994), sedimentou o entendimento de que a Educação Física é uma disciplina curricular que tematiza a Cultura Corporal.

Por fim, em outubro de 1997, a Revista Nova Escola veiculou reportagem que trouxe vários relatos de práticas pedagógicas, que abordaram diversos conteúdos, desenvolvidos por diferentes professores de Educação Física de várias localidades do país. Assim, foi descrito pelo jornalista do impresso que 
Com uma abordagem mais ampla da atividade física, uma geração de professores procura ensinar não só a arte de competir e ganhar, mas acima de tudo a chamada cultura corporal, que trata, na teoria e na prática, da história e dos significados dos movimentos humanos (FIORAVANTI, 1997, p.40).

Dessa maneira, destaco inicialmente, nessa reportagem, o relato da prática pedagógica de um professor de Educação Física da Escola Municipal Henfil, em Recife, Pernambuco, que trabalhou o conteúdo jogo com alunos da segunda série. Assim, foram enfatizadas três atividades realizadas pelo docente. A primeira se reportou as pesquisas que os estudantes fizeram sobre brincadeiras, danças e jogos que eram praticados por seus pais e avós quando crianças, sendo em seguida apresentadas em sala, em que foi constatado que algumas já não existiam e outras sim. Foi informado no impresso que os alunos, dentre os jogos pesquisados, escolheram os que iriam realizar. A segunda atividade relatada consistiu na adoção de jogos populares, como o frevo e a capoeira, com a intenção de ilustrar que meninos e meninas poderiam brincar juntos, o que na observação do professor à revista promoveria nas crianças concentração nos movimentos dos companheiros, de maneira que a atividade apresentava-se mais solidária. Por fim, a terceira prática pedagógica do professor de Recife destacada foi a proposição de mudanças nas regras dos exercícios de modo que a participação de todos os alunos fosse garantida. $\mathrm{O}$ docente relatou na matéria do periódico que era mais difícil adaptar regras de esportes competitivos, a exemplo de vôlei e futebol, e mais fácil tal procedimento com jogos populares (FIORAVANTI, 1997).

Em seguida, nesta mesma reportagem, também foi feito o relato da prática pedagógica de dois professores de Educação Física da escola particular São Domingos, localizada na cidade de São Paulo, com alunos do segundo grau, atual Ensino Médio; e com estudantes da quarta série do primeiro grau, atualmente denominado de Ensino Fundamental. Assim, conforme descrito no periódico, um dos professores de Educação Física, em suas aulas no segundo grau, realizou com os alunos um estudo sobre artes marciais e promoveu um debate sobre corpolatria, ou seja, o culto exarcerbado ao corpo. Segundo veiculado na matéria do impresso, os dois conteúdos foram desenvolvidos por meio de aulas teóricas e que houve resistência dos alunos em relação a essa forma de trabalho do professor. No entanto, foi divulgado que a recusa foi vencida após o estudo de artes marciais, em que a turma realizou pesquisas e debates sobre grupos de capoeira, aikidô e tae kwon do. O docente expressou na revista que os alunos enxergavam na Educação Física somente um espaço de descontração e lazer. Assim, de acordo com o repórter do impresso "Para conciliar seus interesses com os da classe, ele [o professor] alternou discussões e aulas teóricas com a prática de jogos" (FIORAVANTI, 1997, p.45). Em relação ao trabalho sobre corpolatria, foi relatado que o docente fez os alunos examinarem textos de jornais e de revistas, tendo como objetivo "questionar os modismos e mostrar que o excesso de músculos não é necessariamente sinônimo de saúde" (FIORAVANTI, 1997, p.45). Desse modo, de acordo com depoimento do professor na reportagem da revista, é importante que os estudantes aprendam a aferir os aspectos positivos da atividade física para além da escola.

Já em relação ao professor que trabalhou com a quarta série foi descrito que ele desenvolveu os conteúdos dança e futebol. Assim, mesmo sob reação de desaprovação dos alunos do sexo masculino em relação as aulas de dança, que consideravam não ser "coisa de homem", o docente conseguiu trabalhar tal conteúdo e "Com o tempo, [...] driblou os preconceitos e formou grupos por afinidades musicais. [Em que] No final, a classe criou coreografia e se apresentou para a escola" (FIORAVANTI, 1997, p.45). Em relação ao 
trabalho com futebol, o professor pretendeu, conforme sua opinião veiculada na matéria, passar uma visão ampla do esporte e para isso levou a turma a estádios e promoveu debates com jogadores e jornalistas esportivos em que desmistificou a ideia dos alunos de que todo jogador era rico, fazendo-os perceber que de fato a maioria ganha salário mínimo.

Considero relevante registrar que o relato da prática pedagógica do professor pernambucano que trabalhou o conteúdo jogo se diferencia por não tê-lo utilizado como meio para o aprendizado de conteúdos da Matemática e da Língua Portuguesa; e em relação a prática pedagógica desenvolvida no Colégio São Domingos destaca-se o fato de ter sido, no período, o único relato de prática pedagógica com alunos do segundo grau e realizado em uma escola particular, como também a maneira como o professor trabalhou com seus alunos de $4^{\text {a }}$ série o conteúdo esporte, especificamente o futebol, procurando desmistificá-lo enquanto mercado de trabalho (COLETIVO DE AUTORES, 1992).

Por fim, compreendo ser possível inferir que, a despeito de toda discussão acadêmica da Educação Física na década de 1980 e primeiros anos da década de 1990 que conforme Caparroz e Bracht (2007) hipertrofiaram as discussões pedagógicas e atrofiaram as discussões de didática, os professores que, entre 1986 a 1997, enviaram notícias de suas práticas pedagógicas à Revista Nova Escola se preocuparam com o tempo e o lugar de uma didática da Educação Física ${ }^{20}$.

\section{Considerações Finais}

No decorrer desse artigo procurei analisar quais concepções do componente Educação Física historicamente foram veiculadas pela Revista Nova Escola entre 1986 e 1997. Assim foi possível observar que os conteúdos da área que o periódico veiculou foram dispostos de dois modos distintos, sendo um caracterizado no fato do impresso ter publicado reportagens com sugestões de conteúdos e o outro por meio das matérias que veicularam os relatos de práticas pedagógicas de professores de Educação Física de todas as regiões brasileiras em que foi possível verificar os conteúdos desenvolvidos. Em relação as reportagens com sugestões de conteúdos observei que o impresso, entre 1986 a 1997, fase que chamei de adesão à educação pelo movimento, ainda que tenha indicado os conteúdos esportes e exercícios físicos para dramatizar, predominantemente sugeriu o conteúdo jogo e brincadeira dirigido para turmas de $1^{\mathrm{a}}$ a $4^{\mathrm{a}}$ séries, visando desenvolver a cooperação entre os alunos, a criação de regras, o incentivo a participação de meninos e meninas durante as aulas, além de procurar promover o aprendizado de conceitos da Matemática, o que evidencia que o impresso convergiu para a educação pelo movimento que no âmbito da Educação Física corresponde a uma concepção psicologizante da área.

No tocante aos conteúdos presentes nos relatos de práticas pedagógicas dos professores de Educação Física publicados pelo impresso, que em sua maioria atuavam na rede pública de educação, observei que na fase da adesão à educação pelo movimento foram trabalhados, entre outros, os conteúdos atividade física e saúde, jogo e brincadeira, dança, luta, exercícios físicos, ginástica e esporte. Não obstante ter havido uma diversificação de conteúdos trabalhados pelos professores, o conteúdo jogo e brincadeira foi o que esteve presente no maior número de relatos de práticas pedagógicas nessa fase, sendo possível constatar que os docentes na realização de seus trabalhos com este conteúdo procuraram desenvolver em seus alunos a sociabilidade, os aspectos motores e cognitivos, além de utiliza-lo como meio para o aprendizado, sobretudo, das noções de Matemáticas e da Língua Portuguesa, o que evidencia que a maioria dos professores que tiveram seus relatos publicados pela revista, entre 1986 a 1997, aderiu à concepção psicologizante de Educação Física, estando, desse modo, atentos a essa perspectiva da área. 
Porém, verifiquei que as matérias que relataram as experiências educacionais dos professores do Colégio de Aplicação da Universidade Federal de Pernambuco; do professor de Educação Física da Escola Municipal Henfil, em Recife, Pernambuco; de dois professores de Educação Física da escola particular São Domingos, em São Paulo, descreveram relatos de práticas pedagógicas de professores que podem ser inscritas numa concepção crítica de Educação Física, revelando, dessa maneira, que ocorreu no interior da Revista Nova Escola a publicação de uma concepção divergente em relação a orientação psicologizante que predominantemente veiculou para a área. Assim, a partir desse dado, pode-se inferir que o impresso também foi utilizado por esses docentes para divulgar seus trabalhos que eram formulados a partir de suas experiências acadêmicas, profissionais, de visão de mundo e sociedade.

Portanto, constato que entre 1986 a 1997 a Revista Nova Escola veiculou, predominantemente, a concepção psicologizante de Educação Física, que é considerada problemática por despolitizar os processos educativos; no entanto, foi possível constatar que o impresso também veiculou, com menos ênfase, a concepção crítica ou progressista da área. Por fim, entendo ancorado na lógica histórica thompsoniana, não ser adequado pesquisar a Revista Nova Escola a partir de posições autoconfirmadoras.

\section{Referências}

A PEDAGOGIA das velhas brincadeiras de rua. Revista Nova Escola. São Paulo, n.69, p.37-38, set. 1993.

APOSTE nos jogos que as crianças já conhecem. Revista Nova Escola. São Paulo, n. 21, p.20-21, mai. 1988.

BRACHT, V. Educação Física \& Ciência: cenas de um casamento (in)feliz. Ijuí: Unijuí, 1999.

CAPARROZ, F. E. Entre a Educação Física na Escola e a Educação Física da Escola: a Educação Física como componente curricular. Vitória: UFES, Centro de Educação Física e Desportos, 1997.

Física. Disponível em:

; BRACHT, V. O tempo e o lugar de uma didática da Educação

<http://www.rbceonline.org.br/revista/index.php/RBCE/article/view/53>. Acesso em: 01 fev. 2010.

CIVITA, V. Carta do Editor. Revista Nova Escola. São Paulo, n.1, p.5, mar. 1986.

COLETIVO DE AUTORES. Metodologia do ensino da Educação Física. São Paulo: Cortez, 1992.

DAOLIO, J. Educação Física Brasileira: autores e atores da década de 80. Tese

(Doutorado em Educação Física) -.Faculdade Estadual de Campinas, Campinas, 1997.

DÊ CORDA aos seus alunos: com esse material simples e barato, eles promovem muitos jogos que lhes possibilitam um bom desenvolvimento motor, afetivo e social. Revista

Nova Escola. São Paulo, n.30, p.20-21, mai. 1989.

FIORAVANTI, C. Mude as regras do jogo. Revista Nova Escola. São Paulo, n.106, p.4045, out. 1997. 
FRARE, J. L. et al. Educação Física. Revista Nova Escola. São Paulo, n.42, p.10-18, set. 1990.

GINÁSTICA com letras. Revista Nova Escola. São Paulo, n.99, p.16-18, dez. 1996.

GOMES, V. Longe das quadras, perto da natureza. Revista Nova Escola. São Paulo, n.25, p.30-33, out. 1988 .

JOGOS de bola para meninos e meninas. Revista Nova Escola. São Paulo, n.34, p.20-21, out. 1989.

OLIVEIRA, V. M. Consenso e conflito da Educação Física brasileira. Campinas, São Paulo: Papirus, 1994.

PAIVA, F. S. L. Ciência e poder simbólico no Colégio Brasileiro de Ciências do

Esporte. Vitória: Universidade Federal do Espírito Santo. Centro de Educação Física e Desportos, 1994.

PARA suar a cabeça. Revista Nova Escola. São Paulo, n.87, p.40-41, set. 1995.

PEDROSO, L. A. A Revista Nova Escola: política educacional na "Nova República". Tese (Doutorado em Educação) - Faculdade de Educação, Universidade Estadual de Campinas, Campinas, 1999.

RAMOS, M. E. T. O ensino de História na Revista Nova Escola (1986-2002): cultura midiática, currículo e ação docente. Tese (Doutorado em Educação) - Faculdade de Educação, Universidade Federal do Paraná, Curitiba, 2009.

SANCHEZ, A. Revista Nova Escola. São Paulo, n.33, p.3, set. 1989.

Revista Nova Escola. São Paulo, n.38, p.5, abr. 1990.

SAVIANI, D. As concepções pedagógicas na História da Educação brasileira. Disponível em: <http://www.histedbr.fae.unicamp.br/navegando/artigos_frames/artigo_036.html>. Acesso em: 01 jul. 2012.

. A nova lei da educação: trajetória, limites e perspectivas. $11^{\mathrm{a}} \mathrm{ed}$.

Campinas, São Paulo: Autores Associados, 2008.

SILVA, F. C. T. Brasil, em direção ao século XXI. In: LINHARES, M. Y. (Org.) História geral do Brasil. $6^{a}$. Ed. Rio de Janeiro: Campus, 1996. p.335 - 379.

SILVA, M.; FEITOSA, L. S. Revista Nova Escola: legitimação de políticas educacionais e representação docente. 2008. Disponível

em:<http://www.hpopnet.sites.uol.com.br/art14_31.pdf >. Acesso em: 03 mar. 2009.

SILVEIRA, F. R. Um estudo das capas da Revista Nova Escola: 1986 - 2004. 2006. 144

f. Dissertação (Mestrado em Educação) - Faculdade de Educação, Universidade Estadual de Campinas, Campinas, 2006.

TABORDA DE OLIVEIRA, M. A. A Revista Brasileira de Educação Física e Desportos (1968-1984) e a experiência cotidiana de professores da Rede Municipal de Ensino de Curitiba: entre a adesão e a resistência. Tese (Doutorado em Educação) Pontifícia Universidade Católica de São Paulo, São Paulo, 2001.

THOMPSON, E. P. A miséria da teoria ou um planetário de erros: uma crítica ao pensamento de Althusser. Tradução Waltensir Dutra. Rio de Janeiro: Zahar, 1981. 
TIGRE, A. Alunos criam exercícios nas aulas de Educação Física. Revista Nova Escola. São Paulo, n.54, p.44-45, dez. 1991.

VAMOS jogar amarelinha?. Revista Nova Escola. São Paulo, n. 22, p.22-23, abr. 1988.

\section{Notas}

${ }^{1}$ Este artigo é parte da dissertação de mestrado defendida na Universidade Federal de Sergipe intitulada: Concepções pedagógicas de Educação Física na Revista Nova Escola (1986-2010): da adesão à educação pelo movimento à adequação aos PCNs.

${ }^{2}$ Professor do Instituto Federal de Educação, Ciência e Tecnologia da Bahia. Mestre em Educação pela Universidade Federal de Sergipe (UFS). Membro do CEMEFEL/UFS.

${ }^{3}$ http://www.publiabril.com.br/marcas/novaescola/revista/informacoes-gerais.

${ }^{4}$ Notadamente em relação a Revista Nova Escola verifiquei, a partir de levantamento feito no banco de Teses da Capes, que até o ano de 2010 houve a ocorrência de 35 dissertações de mestrado e 11 teses de doutorado que a tomaram como objeto ou fonte para pesquisa.

${ }^{5}$ Nesse processo de redemocratização aconteceram eleições diretas para os governos estaduais em 1982; a ascensão de Tancredo Neves em 1985, por meio de uma eleição indireta, à Presidência da República, decorrente, conforme Silva (1996), de uma transição pactuada; e a aprovação, em 1988, da Constituição Federal que incorporou uma série de direitos civis e sociais.

${ }^{6}$ Conforme Saviani (2008) os educadores brasileiros estavam organizados em tipos diferentes de associações em um processo que teve início na década de 1970 e se fortaleceu no decorrer da década de 1980.

${ }^{7}$ Contudo, é importante frisar que em relação a procura do atleta-aluno, própria do modelo esportivo posto em questão, Taborda de Oliveira (2001) demonstrou que já na década de 1970 no Brasil teve penetração a perspectiva dogmática que pensava na contribuição da Educação Física, por meio das atividades corporais, voltada para a formação integral das pessoas, assim pondo em xeque a tese do transplante cultural e o entendimento de que seus professores fossem alienados e subservientes as determinações oficiais do governo militar.

${ }^{8}$ Sigo na esteira de Saviani (2005) entendendo que uma concepção pedagógica deve envolver o nível da filosofia da educação, o nível da teoria da educação e o nível da prática pedagógica.

${ }^{9}$ Para observar os conteúdos considerei todas as reportagens publicadas no período. Contudo, quando procurei analisar as concepções de Educação Física voltei a atenção para as matérias em que o impresso sugeriu os conteúdos que deveriam ser trabalhados pelos professores da área e os relacionou com as séries do Ensino Fundamental aos quais seriam destinados. Já em relação as reportagens que veicularam os relatos de práticas pedagógicas, centrei a atenção nas reportagens que identificaram, com clareza, as séries do Ensino Fundamental em que o trabalho foi realizado e se a escola em que o professor desenvolveu sua aula pertencia a iniciativa privada ou a rede pública.

${ }^{10}$ Consultar a dissertação de mestrado Concepções pedagógicas de Educação Física na Revista Nova Escola (1986-2010): da adesão à educação pelo movimento à adequação aos PCNs.

${ }^{11}$ Fundada em 1950 por Victor Civita com apoio de seu irmão César Civita, proprietário da Editora Abril na Argentina e representante da Walt Disney Productions na América do Sul. A Editora Abril brasileira inicia suas atividades com a publicação do gibi o Pato Donald e lançou várias revistas de sucesso tais como: Capricho (1952), de fotonovelas; Quatro Rodas (1960), automobilística; Claudia (1961), impresso dirigido ao público feminino; Veja (1968), revista de atualidades; Placar (1970), periódico espotivo. Conforme Ramos (2009, p.45) "embora estas e outras revistas inspirem-se em modelos estrangeiros, a editora adaptou seu conteúdo e organização gráfica de acordo com o 'gosto do brasileiro' [...], de modo a configurar a 'fórmula Abril' de fotojornalismo, que por sua vez determinará a estruturação de Nova Escola”.

12 A revista Escola foi direcionada ao professor de primeiro grau e explicitamente declarou se colocar a serviço da Lei de Diretrizes e Bases da Educação Nacional 5692, de 1971 (PEDROSO, 1999; SILVEIRA, 2006; RAMOS, 2009). Dentre os motivos entendidos como capazes de explicar a interrupção de sua publicação destaca-se a "falta de subsídios oficiais e privados; de um mercado consumidor ainda refratário a esse tipo de revista; de um departamento de assinaturas em estruturação inicial; dos serviços de correio serem desorganizados naquele momento; da estruturação gráfica ser onerosa, o que dificultava a concorrência com outras revistas de banca de jornal; da falta de pesquisa quanto ao perfil do público-leitor, para que se 
definissem a linguagem e o conteúdo a serem adotados; das empresas não confiarem em anunciar seus produtos nas páginas da revista, por conta do baixo poder aquisitivo de grande parte de seus leitores; e, por fim, do julgamento dos editores, os quais acreditavam ser impróprio empregar propaganda em uma revista voltada para a educação"(RAMOS apud ROSEMBERG et al, 2009, p.48).

${ }^{13}$ É relevante registrar que tanto as reportagens que apresentaram as sugestões de conteúdos, quanto as que veicularam os relatos de práticas pedagógicas estão localizadas em seções na revista que, entre 1986 e 1997 , não se mantiveram constantes, deixando de existir ou mudando a nomenclatura.

${ }^{14}$ Trata-se das reportagens veiculadas nas edições 3, 4 (1986), e 37 (1990)

${ }^{15}$ Silveira (2006) afirmou que quando a Revista Nova Escola traz para ser o tema principal de suas capas as disciplinas escolares, existe a predominância das capas relacionadas ao ensino de Português, o que possibilita perceber sua preferência em relação às questões afetas à alfabetização.

${ }^{16}$ Principal representante da perspectiva desenvolvimentista de Educação Física que se debruça nos estudos sobre desenvolvimento motor, aprendizagem motora e controle motor, e traz como ponto central a afirmação de que o objeto de estudo da Educação Física é o movimento humano, sendo sua especificidade, notadamente nas séries iniciais, a promoção da aprendizagem do movimento. Para Oliveira (1994) a perspectiva desenvolvimentista possui dois aspectos positivos. Nesse sentido, indicou a boa crítica da proposta à iniciação esportiva precoce, como também considerou acertada a afirmação de que o movimento humano é o principal interesse da Educação Física, podendo ser estudado nos níveis bioquímico, neurofisiológico, comportamental e social. No entanto, a perspectiva de Educação Física desenvolvimentista sofre severas críticas. Assim, quando seu principal elaborador afirmou que a promoção da aprendizagem do movimento é a especificidade da Educação Física produziu, de acordo com Daolio (1997), as maiores polêmicas com o grupo marxista, já que estes entendem que a área concebida nestes termos se reduz aos aspectos biológicos e desconsidera suas implicações sociais. Nessa mesma direção Oliveira (1994) atestou que mesmo a proposta tendo levado em conta que as dimensões humanas são biológica, social, cultural e cognitiva apresentou e deu atenção de forma preponderante os aspectos biológicos. E por fim, no mesmo tom de crítica Caparroz (1997, p.164), com um olhar mais dirigido para a escola, argumentou que a proposta desenvolvimentista não traz "um aprofundamento sobre a forma como a Educação Física escolar deve proceder a seleção do conteúdo no seio da cultura, não há consideração sobre como esta área opera a conversão do conhecimento acerca do movimento humano em saber escolar".

${ }^{17}$ Com seu livro Educação de Corpo Inteiro, publicado em 1989, faz uma proposta para a Educação Física escolar, notadamente para as séries iniciais, discutindo-a teoricamente e apresentando também um grande número de atividades, principalmente brinquedos e jogos, para serem aplicados nas aulas (OLIVEIRA, 1994). Para Daolio (1997) a proposta veiculada nesta literatura critica fortemente a escola na medida em que explicitou que esta instituição nega a cultura infantil, enfatiza uma educação pouco significativa à criança, não favorecendo sua individualidade e barrando sua liberdade. Assim, indicou que a proposta do professor João Batista Freire valoriza o conhecimento espontâneo de jogos, brincadeiras e atividades motoras inerentes à criança indo, desse modo, favorecer uma educação de corpo inteiro em que não apenas a cabeça da criança estivesse na escola, mas seu corpo. Outros aspectos encarados como méritos da proposta que quer o corpo do aluno na escola se consubstanciam na medida que em sua perspectiva, de acordo com Oliveira (1994), a avaliação quantitativa sofre grande oposição, não há separação entre meninos e meninas nas aulas e os métodos de ensino tradicionais são fortemente questionados. Contudo, algumas ressalvas são feitas a educação de corpo inteiro, sendo uma das mais consistentes o fato de que mesmo com o reconhecimento de que João Batista Freire alertou para o fato de que a Educação Física não se tornasse disciplina auxiliar de outras na escola, foi dado por ele muita importância, em sua proposta, a possibilidade de que por meio das atividades corporais se obtivesse conhecimentos, principalmente, da matemática e do cálculo (OLIVEIRA, 1994). Desse modo, a partir da verificação desses elementos entendo que a educação de corpo inteiro também pode ser compreendida como educação pelo movimento.

${ }^{18}$ Nestas 14 matérias foram feitos 26 relatos de práticas pedagógicas. Cabe ressaltar que em alguns relatos foi possível observar que os professores trabalharam mais de um conteúdo.

${ }^{19}$ O CBCE, criado em 1978, foi palco de acirradas disputas entre os profissionais ligados à Educação Física, e de acordo com Paiva (1994, p.82) tem papel importante no pensamento acadêmico da área no Brasil, e "funcionou (funciona) como um dos espaços sociais de legitimação de sentidos; de definição do que é ciência, esporte, ciência do esporte e educação física". A autora afirmou que a instituição até 1985 entendeu que a Educação Física deveria capacitar fisicamente os indivíduos e seria a prática de atividade física sistemática ou assistematicamente; entre 1985 a 1989 compreendeu que a Educação física é uma atividade escolar que deve saber oferecer e avaliar experiências motrizes adequadas a faixa etária e a individualidade 
de cada aluno, calcada nos princípios físiológicos e neuro-motores; e entre 1989 a 1993 consolidou-se em seu interior o entendimento de que a Educação física é uma disciplina curricular que deve tematizar o movimento humano, a cultura física e/ou a cultura corporal. Por fim, considero relevante registrar que o CBCE procurou imprimir essa última perspectiva de Educação Física escolar para além de seus sócios, eventos científicos e publicações sendo isso visualizado quando, por exemplo, participou do Fórum Nacional em Defesa da Escola Pública e quando foi aceito, em 1988, no quadro associativo das instituições que formam a Sociedade Brasileira para o Progresso da Ciência (SBPC), e teve assegurado a possibilidade de "diálogo e a interação com outras entidades científicas com poder de intervenção nas discussões acerca das políticas de ciência e tecnologia do país"(PAIVA, 1994, p.180).

${ }^{20}$ Aqui faço alusão ao célebre texto de Caparroz e Bracht (2007) intitulado: O tempo e o lugar de uma didática da Educação Física, em que consideram ser possível que os professores sejam os autores de sua prática pedagógica diante de uma didática repensada.

Recebido em setembro/13

Aprovado em março/14 